\title{
Article \\ Process Optimization of Electrochemical Treatment of COD and Total Nitrogen Containing Wastewater
}

\author{
Jiachao Yao ${ }^{1}$, Yu Mei ${ }^{1}$, Junhui Jiang ${ }^{2}$, Guanghua Xia ${ }^{3}$ and Jun Chen ${ }^{1, *}$ \\ 1 College of Biology and Environmental Engineering, Zhejiang Shuren University, Hangzhou 310015, China; \\ jcyao@zjut.edu.cn (J.Y.); imy1220@zjut.edu.cn (Y.M.) \\ 2 The Engineering Technology Center of Pollution Control in Taizhou, Taizhou 318000, China; \\ 14060601003@pop.zjgsu.edu.cn \\ 3 College of Life Science, Taizhou University, Taizhou 318000, China; zhouwuluyao@sjtu.edu.cn \\ * Correspondence: bec@zjut.edu.cn; Tel.: +86-571-8832-0448
}

check for

updates

Citation: Yao, J.; Mei, Y.; Jiang, J.; Xia, G.; Chen, J. Process Optimization of Electrochemical Treatment of COD and Total Nitrogen Containing Wastewater. Int. J. Environ. Res. Public Health 2022, 19, 850. https://doi.org/ $10.3390 /$ ijerph19020850

Academic Editor: Barbara Ruffino

Received: 10 November 2021

Accepted: 13 December 2021

Published: 13 January 2022

Publisher's Note: MDPI stays neutral with regard to jurisdictional claims in published maps and institutional affiliations.

Copyright: (c) 2022 by the authors. Licensee MDPI, Basel, Switzerland This article is an open access article distributed under the terms and conditions of the Creative Commons Attribution (CC BY) license (https:// creativecommons.org/licenses/by/ $4.0 /$ )

\begin{abstract}
In this work, an electrochemical method for chemical oxygen demand (COD) and total nitrogen (TN, including ammonia, nitrate, and nitrite) removal from wastewater using a divided electrolysis cell was developed, and its process optimization was investigated. This process could effectively relieve the common issue of $\mathrm{NO}_{3}{ }^{-} / \mathrm{NO}_{2}{ }^{-}$over-reduction or $\mathrm{NH}_{4}{ }^{+}$over-oxidation by combining cathodic $\mathrm{NO}_{3}{ }^{-} / \mathrm{NO}_{2}{ }^{-}$reduction with anodic $\mathrm{COD} / \mathrm{NH}_{4}{ }^{+}$oxidation. The activity and selectivity performances toward pollutant removal of the electrode materials were investigated by electrochemical measurements and constant potential electrolysis, suggesting that Ti electrode exhibited the best $\mathrm{NO}_{3}{ }^{-} / \mathrm{NO}_{2}{ }^{-}$reduction and $\mathrm{N}_{2}$ production efficiencies. In-situ Fourier transform infrared spectroscopy was used to study the in-situ electrochemical information of pollutants conversion on electrode surfaces and propose their reaction pathways. The effects of main operating parameters (i.e., initial $\mathrm{pH}$ value, $\mathrm{Cl}^{-}$concentration, and current density) on the removal efficiencies of COD and TN were studied. Under optimal conditions, COD and TN removal efficiencies from simulated wastewater reached $92.7 \%$ and $82.0 \%$, respectively. Additionally, reaction kinetics were investigated to describe the COD and TN removal. Results indicated that COD removal followed pseudo-first-order model; meanwhile, TN removal followed zero-order kinetics with a presence of $\mathrm{NH}_{4}{ }^{+}$and then followed pseudo-first-order kinetics when $\mathrm{NH}_{4}{ }^{+}$was completely removed. For actual pharmaceutical wastewater treatment, 79.1\% COD and 87.0\% TN were removed after $120 \mathrm{~min}$ electrolysis; and no $\mathrm{NH}_{4}{ }^{+}$or $\mathrm{NO}_{2}{ }^{-}$was detected.
\end{abstract}

Keywords: electrochemical oxidation; electrochemical reduction; COD; total nitrogen; wastewater treatment

\section{Introduction}

A large quantity of wastewater produced from industrial manufacturing process is contaminated by two often-regulated primary contaminants: organic matter and nutrients, such as nitrogen in the forms of ammonia, nitrate, and nitrite [1,2]. Biological technology has been considered an effective method for chemical oxygen demand (COD) and total nitrogen $(\mathrm{TN})$ removal from wastewater [3,4], but rigorous monitoring (e.g., $\mathrm{pH}$, temperature) is needed to maintain daily operations $[5,6]$. Several other methods, such as membrane filtration [7,8], ion exchange [9,10], and adsorption [11], are also extensively used to remove COD and nitrogen contamination; however, these techniques may result in secondary pollution [12,13].

Electrochemical method is proposed as a promising alternative for wastewater treatment because of its high efficiency, versatility, easy operation, and environmental compatibility [14-16]. Ganzoury et al. [17] summarized that, compared with traditional biological technology, the electrochemical method is much more suitable for removal of persistent color and pollutants from wastewater. In recent literatures, many scholars investigated the 
anodic oxidation of COD or $\mathrm{NH}_{4}{ }^{+}$and proved the superiority of electrochemical wastewater treatment $[18,19]$. For example, Zöllig et al. [20] reported that, for real stored urine treatment by electrochemical method, ammonia could be efficiently removed by direct and indirect oxidation. In addition, many researches focusing on cathodic reduction of $\mathrm{NO}_{3}{ }^{-}$or $\mathrm{NO}_{2}{ }^{-}$have been reported [21,22]. Su et al. [13] presented the performances of $\mathrm{Co}_{3} \mathrm{O}_{4} / \mathrm{Ti}, \mathrm{Fe}_{2} \mathrm{O}_{3} / \mathrm{Ti}$, and $\mathrm{Cu}$ cathodes on $\mathrm{NO}_{3}{ }^{-}$removal, and $\mathrm{Co}_{3} \mathrm{O}_{4} /$ Ti exhibited better $\mathrm{NO}_{3}{ }^{-}$removal efficiency.

Current studies for wastewater treatment by electrochemical method mainly concentrate on the removal of a single pollutant or two mixed pollutants, and there are few investigations on the electrochemical treatment of wastewater containing COD, $\mathrm{NH}_{4}{ }^{+}$, $\mathrm{NO}_{3}{ }^{-}$, and $\mathrm{NO}_{2}{ }^{-}$. In our previous work [23], the feasibly of simultaneous removal of COD and TN was proven; however, it should be noticed that one of the issues for COD and TN removal is to restrain the problems of side reactions of $\mathrm{NH}_{4}{ }^{+}$over-oxidation on anode and $\mathrm{NO}_{3}{ }^{-} / \mathrm{NO}_{2}{ }^{-}$over-reduction on cathode. Actually, many literatures indicate that the over-oxidation or over-reduction is a common phenomenon in the process of nitrogen-containing wastewater treatment by electrochemical method [24-26], which means that the TN removal is limited. For instance, Shih et al. [27] studied the electrochemical performance of ammonia oxidation over a modified nickel foam electrode. The results indicated that, though high ammonia removal rate was achieved, $\mathrm{N}$-atom was easily over-oxidized to $\mathrm{NO}_{3}{ }^{-}$and $\mathrm{NO}_{2}{ }^{-}$. Li at al. [28] investigated the $\mathrm{NO}_{3}{ }^{-}$reduction with Fe cathode, and the concentration of $\mathrm{NO}_{3}{ }^{-}$decreased from 100.0 to $7.2 \mathrm{mg}-\mathrm{N} \cdot \mathrm{L}^{-1}$ in $3 \mathrm{~h}$, but $51.1 \mathrm{mg}-\mathrm{N} \cdot \mathrm{L}^{-1} \mathrm{NH}_{4}{ }^{+}$was generated as the by-product. In order to relieve the issue of over-reduction/oxidation, it is essential to find a suitable reaction cell and key operating parameters to perform the balance between cathodic reduction and anodic oxidation. Li et al. [29] and Mandal et al. [30] reported that a divided cell was more proper for electrochemical denitrification than undivided cell thanks to the ion-exchange membrane, which could reduce the interactions between anodic and cathodic reactions. Many investigators [31,32] also presented that operating parameters, e.g., electrode material, current density, $\mathrm{NaCl}$ concentration, $\mathrm{pH}$, flow rate, and temperature, could strongly affect the electrochemical performance of pollutant removal.

In this work, an electrochemical process for COD and TN removal was optimized, and its feasibility to relieve the issue of over-oxidation or over-reduction was evaluated. $\mathrm{Ti}, \mathrm{Cu}$, and stainless steel were selected as cathode material to study their reduction performance for $\mathrm{NO}_{3}{ }^{-} / \mathrm{NO}_{2}{ }^{-}$removal. The in-situ electrochemical information of COD $/ \mathrm{NH}_{4}{ }^{+}$oxidation and $\mathrm{NO}_{3}{ }^{-} / \mathrm{NO}_{2}{ }^{-}$reduction on electrode surfaces were explored by in-situ Fourier transform infrared spectroscopy (in-situ FTIR). The key operating parameters, i.e., initial $\mathrm{pH}$ value, chloride concentration, and current density, were studied to perform cathodic reduction of $\mathrm{NO}_{3}{ }^{-} / \mathrm{NO}_{2}{ }^{-}$and anodic oxidation of $\mathrm{COD} / \mathrm{NH}_{4}{ }^{+}$. Additionally, kinetics and reaction mechanism were also proposed to describe the redox process. Finally, an actual pharmaceutical wastewater was investigated to verify the electrochemical performance for COD and TN removal.

\section{Materials and Methods}

\subsection{Wastewater Characteristics}

Simulated wastewater containing COD and TN was prepared by dissolving ethyl acetate, ammonium sulfate, sodium nitrate, and sodium nitrite into $0.1 \mathrm{~mol} \mathrm{~L}^{-1} \mathrm{Na}_{2} \mathrm{SO}_{4}$ solution. Sodium chloride was added into the solution to maintain the concentration of chloride ion. Actual pharmaceutical wastewater, which was characterized by low biodegradability and complex composition, was collected from a pharmaceutical factory (Zhejiang, China). The wastewater characteristics are summarized in Table 1. 
Table 1. The main characteristics of the applied wastewater.

\begin{tabular}{|c|c|c|}
\hline Parameters & Simulated Wastewater & Actual Wastewater \\
\hline $\mathrm{pH}$ & $6.0 \pm 0.1$ & $8.1 \pm 0.2$ \\
\hline $\mathrm{COD} / \mathrm{mg} \cdot \mathrm{L}^{-1}$ & $250 \pm 15$ & $337.57 \pm 20$ \\
\hline Total nitrogen $(\mathrm{TN}) / \mathrm{mg}-\mathrm{N} \cdot \mathrm{L}^{-1}$ & $105 \pm 10$ & $120.53 \pm 15$ \\
\hline Ammonia $\left(\mathrm{NH}_{4}^{+} / \mathrm{NH}_{3}\right) / \mathrm{mg}-\mathrm{N} \cdot \mathrm{L}^{-1}$ & $60 \pm 5$ & $87.88 \pm 8$ \\
\hline Nitrate $\left(\mathrm{NO}_{3}^{-}\right) / \mathrm{mg}-\mathrm{N} \cdot \mathrm{L}^{-1}$ & $30 \pm 3$ & $28.33 \pm 5$ \\
\hline Nitrite $\left(\mathrm{NO}_{2}^{-}\right) / \mathrm{mg}-\mathrm{N} \cdot \mathrm{L}^{-1}$ & $15 \pm 2$ & $4.32 \pm 3$ \\
\hline Chloride $\left(\mathrm{Cl}^{-}\right) / \mathrm{mg} \cdot \mathrm{L}^{-1}$ & $0 \sim 1500$ & $987.95 \pm 35$ \\
\hline
\end{tabular}

\subsection{Experimental Setup}

Electrochemical experiments were conducted in a divided electrolysis cell (Figure S1). $\mathrm{Ti} / \mathrm{PbO}_{2}$ electrode $(10 \mathrm{~cm} \times 10 \mathrm{~cm})$ was used as anode, while $\mathrm{Ti}, \mathrm{Cu}$, and stainless steel were selected as cathode, respectively. A volume of $600 \mathrm{~mL}$ wastewater was circulated between anode and cathode chamber by a peristaltic pump.

Electrochemical measurements (i.e., steady-state polarization curves and linear sweep voltammograms) and constant potential electrolysis were executed for the choice of a proper cathode with an electrochemical workstation. The different cathodes were used as the working electrode; platinum sheet and saturated calomel electrode (SCE) were employed as the counter and reference electrode, respectively. In-situ FTIR spectra were obtained by a FTIR spectrometer equipped with a self-made spectroelectrochemical cell (Figure S2).

\subsection{Analytical Methods}

$\mathrm{COD}, \mathrm{TN}$, and ammonia were determined by the dichromate, alkaline potassium persulfate, and Nessler reagent spectrophotometry, respectively $[4,13]$. Anions (e.g., nitrate, nitrite, and chloride) were determined by ion chromatography. Nitrogen oxides were monitored by gas chromatography. The pollutant removal efficiency, product selectivity, and energy consumption were calculated based on our previous work [33].

\section{Results}

\subsection{The Choice of a Proper Electrode}

In the electrochemical system for COD and TN removal, both anode and cathode materials are conclusive for optimizing the redox process [34]. The investigations of anode selection had been reported in our previous work: commercial electrode materials of $\mathrm{Ti} / \mathrm{PbO}_{2}, \mathrm{Ti} / \mathrm{IrO}, \mathrm{Ti} / \mathrm{RuO}_{2}$, and $\mathrm{BDD}$ were compared for treatment of typical industrial wastewater, suggesting that $\mathrm{Ti} / \mathrm{PbO}_{2}$ anode was suitable for $\mathrm{COD}$ and $\mathrm{NH}_{4}{ }^{+}$ removal $[35,36]$. Similarly, cathode material plays an important role in electrochemical denitrification. From the view of practical applications, $\mathrm{Ti}, \mathrm{Cu}$, and stainless steel were selected as cathode materials in this work to study the electrochemical properties and $\mathrm{NO}_{3}{ }^{-} / \mathrm{NO}_{2}{ }^{-}$removal efficiencies due to their high stability and low cost.

Figure 1a shows the steady-state polarization curves of the hydrogen evolution reactions using three cathodes at a scan rate of $10 \mathrm{mV} \cdot \mathrm{s}^{-1}$. Results indicated that Ti electrode had a hydrogen evolution potential of $-1.542 \mathrm{~V}$, which was more negative than those of $\mathrm{Cu}(-1.532 \mathrm{~V})$ and stainless steel $(-1.466 \mathrm{~V})$, meaning that a side reaction of hydrogen evolution was least likely to occur on Ti electrode. Figure $1 \mathrm{~b}$ presents the linear sweep voltammograms of three electrodes on $\mathrm{NO}_{3}{ }^{-} / \mathrm{NO}_{2}{ }^{-}$reduction. Obvious cathodic peaks and extended broad waves were observed with the addition of $\mathrm{NO}_{3}{ }^{-} / \mathrm{NO}_{2}{ }^{-}$into the blank solution, which meant the direct $\mathrm{NO}_{3}{ }^{-} / \mathrm{NO}_{2}{ }^{-}$reduction occurred. Cathodic peaks of $\mathrm{Ti}, \mathrm{Cu}$, and stainless steel were at about $-1.10,-0.99$, and $-0.82 \mathrm{~V}$ for $\mathrm{NO}_{3}{ }^{-}$reduction, respectively. For $\mathrm{NO}_{2}{ }^{-}$reduction, cathodic peaks of -0.68 and $-0.81 \mathrm{~V}$ were observed for $\mathrm{Ti}$ and stainless steel (not observed on $\mathrm{Cu}$ ), respectively. 

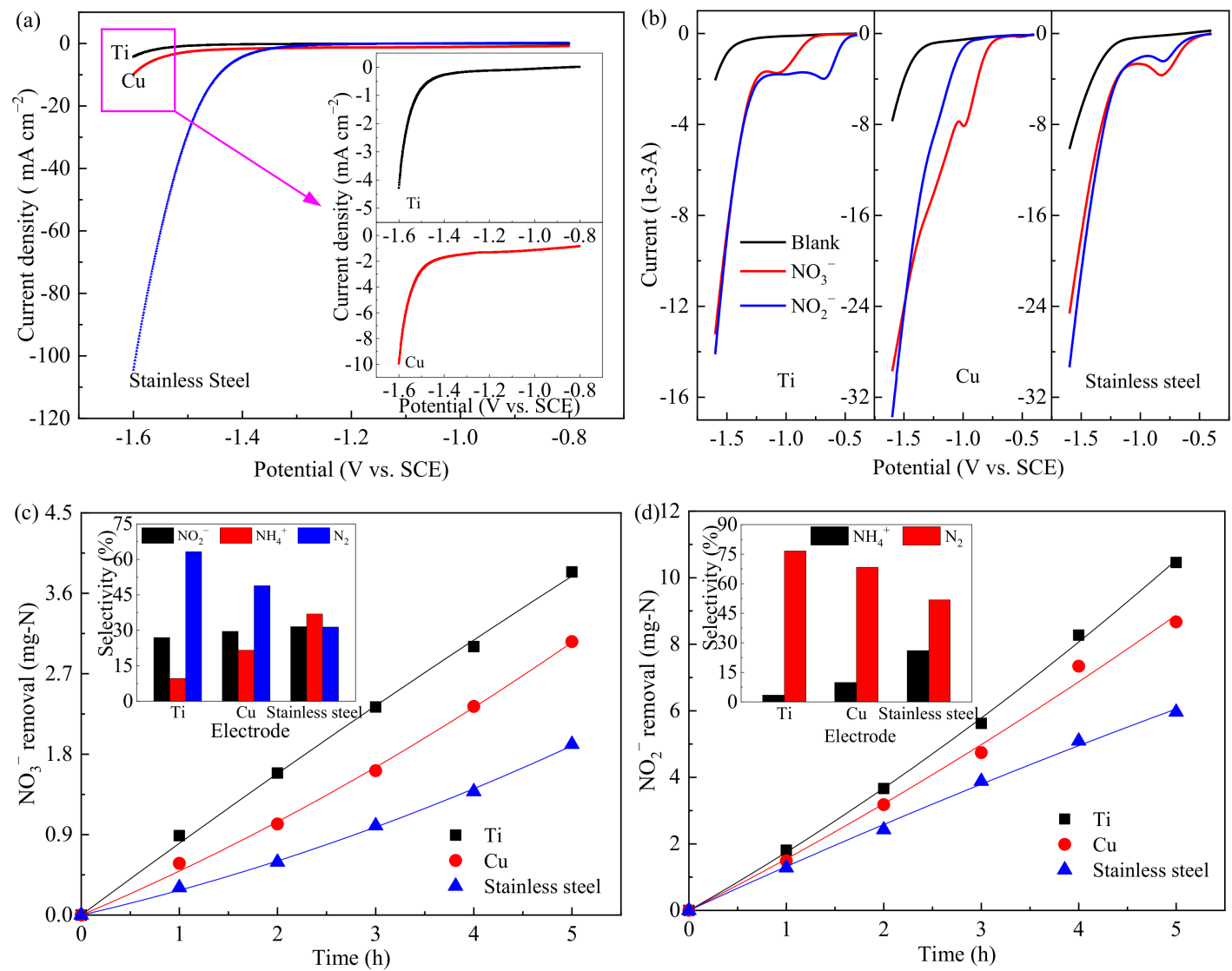

Figure 1. Electrode characterization and pollutant removal. (a) Steady-state polarization curves; (b) linear sweep voltammograms (blank: $0.1 \mathrm{~mol} \cdot \mathrm{L}^{-1} \mathrm{Na}_{2} \mathrm{SO}_{4}$ ); (c) $\mathrm{NO}_{3}{ }^{-}$reduction $\left(0.1 \mathrm{~mol} \mathrm{~L}-1 \mathrm{Na}_{2} \mathrm{SO}_{4}\right.$ $+\mathrm{NO}_{3}{ }^{-}$solution), and the inset shows the selectivity of nitrogen species after 5-h electrolysis; (d) $\mathrm{NO}_{2}{ }^{-}$reduction $\left(0.1 \mathrm{~mol} \cdot \mathrm{L}^{-1} \mathrm{Na}_{2} \mathrm{SO}_{4}+\mathrm{NO}_{2}{ }^{-}\right.$solution), and the inset shows the nitrogen species after 5-h electrolysis.

The removal and selectivity of $\mathrm{NO}_{3}{ }^{-} / \mathrm{NO}_{2}{ }^{-}$reduction with three electrodes at a constant potential of $-1.26 \mathrm{~V}$ are shown in Figure $1 \mathrm{c}$, d. Figure $1 \mathrm{c}$ displays that the highest electrocatalytic performance for $\mathrm{NO}_{3}{ }^{-}$reduction was obtained with the Ti cathode, while that with stainless steel was the lowest. The inset of Figure 1c indicates that $\mathrm{NO}_{2}{ }^{-}$and $\mathrm{NH}_{4}{ }^{+}$were the intermediates or by-products during the $\mathrm{NO}_{3}{ }^{-}$reduction process $[37,38]$. The order of $\mathrm{N}_{2}$ selectivity of these three electrodes was $\mathrm{Ti}(63.3 \%)>\mathrm{Cu}(48.9 \%)>$ stainless steel $(31.5 \%)$. This result might be related to the relative hydrogen evolution potential shown in Figure 1a. Su et al. [13] and Reyter et al. [39] presented that $\mathrm{NH}_{4}{ }^{+}$as the $\mathrm{NO}_{3}{ }^{-}$ reduction by-product was favored in a potential region closing to the hydrogen evolution reaction region; in other words, more negative hydrogen evolution potential led to higher $\mathrm{N}_{2}$ selectivity. The information regarding $\mathrm{NO}_{2}{ }^{-}$reduction from wastewater with different cathodes as working electrode is shown in Figure 1d. The amounts of $\mathrm{NO}_{2}{ }^{-}$reduction for $\mathrm{Ti}, \mathrm{Cu}$, and stainless steel were 10.46, 8.67, and $5.96 \mathrm{mg}-\mathrm{N}$ in $5 \mathrm{~h}$; the $\mathrm{N}_{2}$ selectivities with these three electrodes were $76.6 \%, 68.4 \%$, and $51.8 \%$, respectively. According to the results shown in Figure 1, the electrochemical properties and catalytic activities of the three cathodes for $\mathrm{NO}_{3}{ }^{-} / \mathrm{NO}_{2}{ }^{-}$reduction decreased in the following order: $\mathrm{Ti}>\mathrm{Cu}>$ stainless steel; the Ti electrode was therefore selected for subsequent experiments to study the optimal reaction conditions.

\subsection{In-Situ FTIR Studies on Pollutants Removal}

To explore solid/liquid interfacial phenomena, i.e., identify the intermediates, adsorbed species, and products during pollutants removal, in-situ FTIR spectroscopy was 
applied in the studies of oxidation and reduction processes (Figure 2). In the spectrum, a positive band represents the consumption of compound, and a negative band represents the generation of product.

(a)

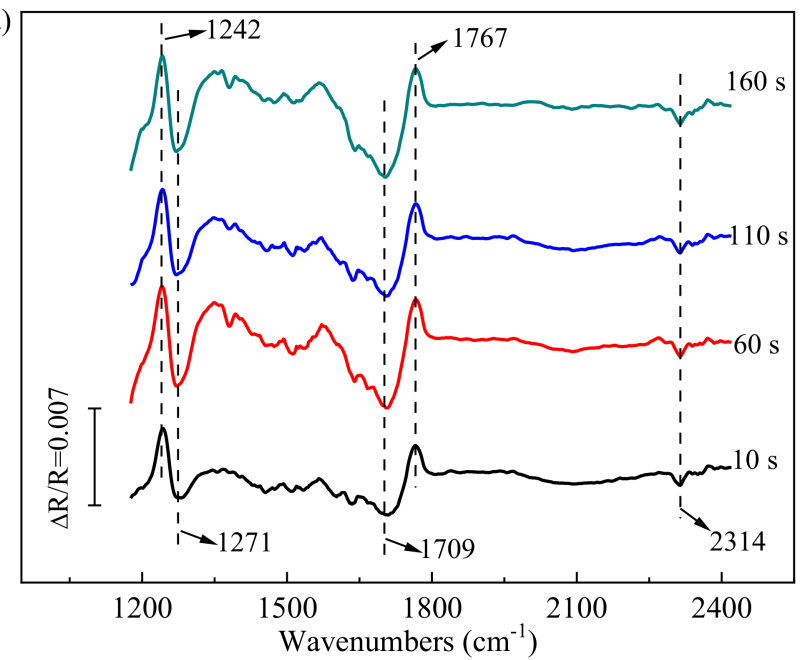

(c)

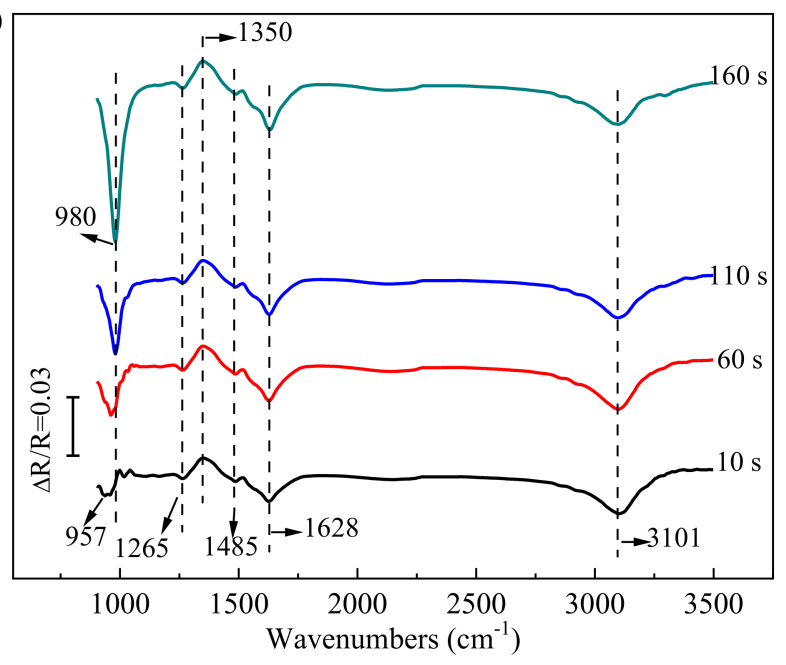

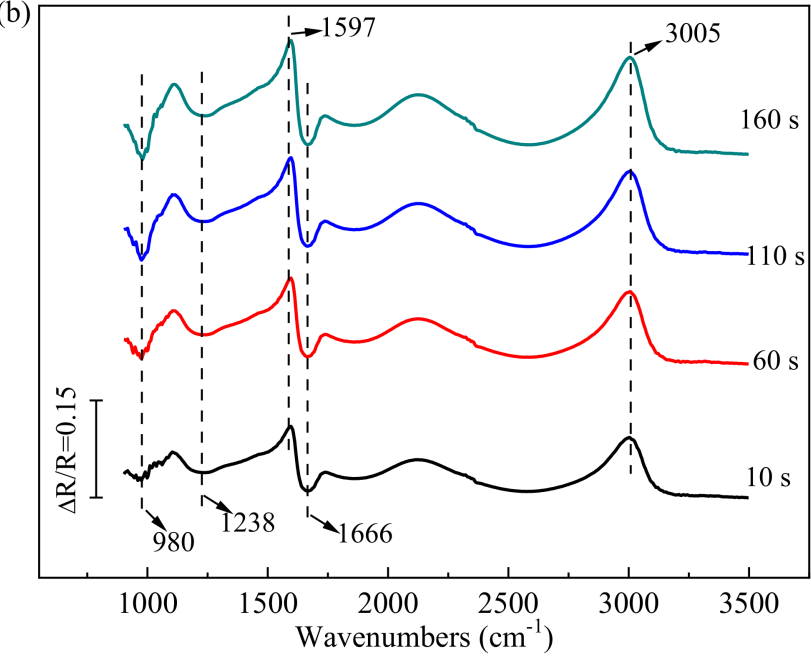

(d)

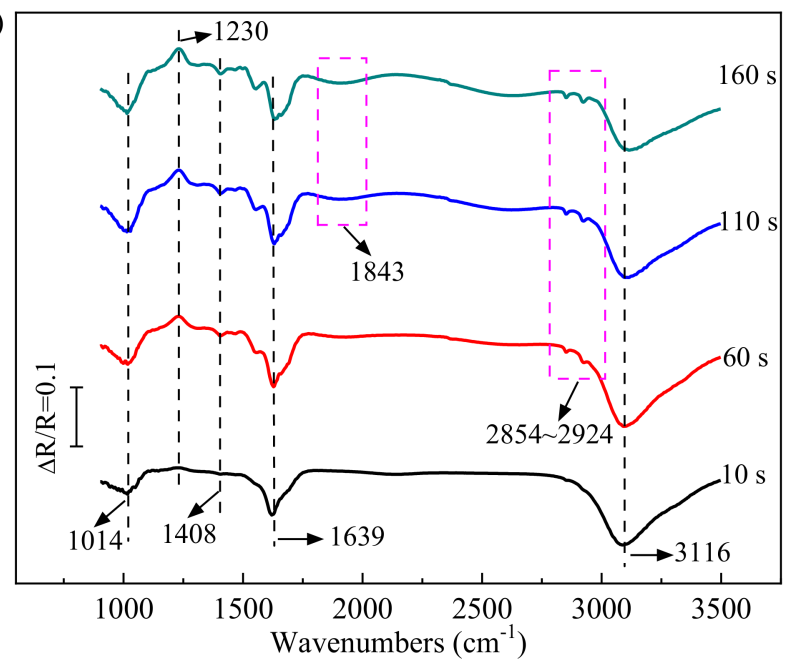

Figure 2. In-situ FTIR spectra collected in electrolysis of COD (a), $\mathrm{NH}_{4}{ }^{+}(\mathbf{b}), \mathrm{NO}_{3}{ }^{-}$(c), and $\mathrm{NO}_{2}{ }^{-}$ (d) solution with electrolysis time.

As shown in Figure 2a, the ester bond of the organic is confirmed at the positive bands of 1242 and $1767 \mathrm{~cm}^{-1}$ during COD electro-oxidation. Two negative infrared (IR) bands are observed at about 1271 and $1709 \mathrm{~cm}^{-1}$, representing the $\mathrm{C}-\mathrm{OH}$ and $\mathrm{C}=\mathrm{O}$ scissors vibration in $\mathrm{COOH}$, respectively. The downward band at $2314 \mathrm{~cm}^{-1}$ is assigned to $\mathrm{CO}_{2}$ absorption. The results indicated that the organic matter was decomposed to low molecule acid and then converted to $\mathrm{CO}_{2}$.

Figure $2 \mathrm{~b}$ shows that the vibrations of $\mathrm{NH}_{4}{ }^{+}$are detected at 1597 and $3005 \mathrm{~cm}^{-1}$. The weak bands located at 980 and $1666 \mathrm{~cm}^{-1}$ represent the absorption of $\mathrm{NH}_{3 \text {,ads }}$. Besides, dispersed bands are observed around $2000-3000 \mathrm{~cm}^{-1}$. According to the study by Griffiths and Haseth [40], the complex bands may be attributed to the vibrations of $\mathrm{NH}_{3}{ }^{+}$, $\mathrm{NH}_{2}{ }^{+}$, and $\mathrm{NH}^{+}$. A band at $1238 \mathrm{~cm}^{-1}$ can be also observed, indicating the generation of $\mathrm{NO}_{2}{ }^{-}$[40]. Though $\mathrm{NO}_{2}{ }^{-}$band was observed, the vibration of $\mathrm{NO}_{3}{ }^{-}$was not shown. This phenomenon might be related to the operating conditions. For example, Kapałka et al. [41] indicated that ammonia removal and product distribution were strongly $\mathrm{pH}$ dependent. Likewise, operating parameters, e.g., chloride concentration and current density, could also affect the distribution of products during $\mathrm{NH}_{4}{ }^{+}$electro-oxidation because of the concentra- 
tions of generated active radicals, which was reported by Anglada et al. [42]. On the basis of experimental results, a simple reaction route of $\mathrm{NH}_{4}{ }^{+}$electro-oxidation in this system was proposed as shown in Equation (1):

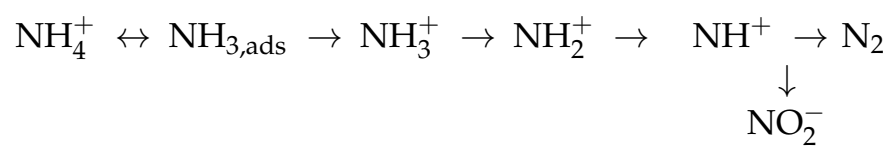

The in-situ FTIR spectra measured during electro-reduction of $\mathrm{NO}_{3}{ }^{-}$are given in Figure 2c. The IR absorption at $1350 \mathrm{~cm}^{-1}$ is ascribed to the existence of $\mathrm{NO}_{3}{ }^{-}$. The peak of $1265 \mathrm{~cm}^{-1}$ suggests the presence of $\mathrm{NO}_{2}{ }^{-}$in electrolysis. Dispersed bands are presented at ca. $1800-3000 \mathrm{~cm}^{-1}$, indicating the vibrations of $\mathrm{NH}_{2}{ }^{+}$and $\mathrm{NH}_{3}{ }^{+}$[43]. Three characteristic IR bands at 957-980, 1628, and $3101 \mathrm{~cm}^{-1}$ are observed and assigned to absorbed $\mathrm{NH}_{3 \text {,ads }}$, and the weak band at $1485 \mathrm{~cm}^{-1}$ is confirmed as $\mathrm{NH}_{4}{ }^{+}$. As shown in Figure $2 \mathrm{~d}$, the band for $\mathrm{NO}_{2}{ }^{-}$appears at $1230 \mathrm{~cm}^{-1}$. Similar to the spectra of $\mathrm{NO}_{3}{ }^{-}, \mathrm{NH}_{3}$,ads generated at the bands of 1014, 1639, and $3116 \mathrm{~cm}^{-1}$ in the electro-reduction of $\mathrm{NO}_{2}{ }^{-}$, and then, the $\mathrm{NH}_{4}{ }^{+}$ is detected at $1408 \mathrm{~cm}^{-1}$. Additionally, weak bands at about 1843 and $2854-2924 \mathrm{~cm}^{-1}$ are discovered with electrolysis time, which are ascribed to volatile by-products of NO and $\mathrm{NO}_{2}$, respectively [44]. Similar to the condition of $\mathrm{NH}_{4}{ }^{+}$oxidation, nitrate/nitrite reduction and products distribution also highly rely on operating parameter, such as optimum voltage, electrode distance, and initial $\mathrm{pH}$ [45]. In this electrochemical system, the $\mathrm{NO}_{3}{ }^{-} / \mathrm{NO}_{2}{ }^{-}$electro-reduction mechanism was speculated in Equation (2), according to the FTIR spectra.

$$
\begin{aligned}
\mathrm{NO}_{3}^{-} \rightarrow \underset{ }{ } & \mathrm{NO}_{2}^{-} \rightarrow \quad \mathrm{NH}_{2}^{+} \rightarrow \mathrm{NH}_{3}^{+} \rightarrow \mathrm{NH}_{3, \mathrm{ads}} \leftrightarrow \mathrm{NH}_{4}^{+} \\
& \mathrm{N}_{2} \mathrm{NO} \rightarrow \mathrm{NO}_{2}
\end{aligned}
$$

\subsection{Main Factors on COD and TN Removal}

As stated above, operating parameters can make great influences on the performance of electrochemical process; moreover, actual wastewater is known for its characteristics of complexity and variety. Therefore, main factors, including initial $\mathrm{pH}$ value, chloride concentration, and current density, were investigated on COD and TN removal.

\subsubsection{Effect of Initial $\mathrm{pH}$ Value}

Figure 3 presents the variations of $\mathrm{COD}$ and $\mathrm{TN}$ removal as a function of initial $\mathrm{pH}$ value. The COD removal efficiency decreased with the increase of $\mathrm{pH}$ value. However, the $\mathrm{TN}$ removal increased with the increase of $\mathrm{pH}$ value in acidic and non-acidic conditions, respectively. The inset of Figure 3a presents that a linear relationship was observed between the logarithm of COD concentration and electrolysis time; i.e., pseudo-first-order kinetics model emerged. Table S1 displays the apparent reaction rate constants $\mathrm{K}$. As shown, the value of $\mathrm{K}$ at $\mathrm{pH} 3$ was about 1.6 times that of $\mathrm{pH} 11$, suggesting that COD removal was more favorable in acidic solution, which was in agreement with the findings by Chen et al. [32] and Zhao et al. [46]. Figure $3 \mathrm{~b}$ shows that zero-order kinetics provided a suitable description of TN removal, and the rate constants $\mathrm{K}^{\prime}$ were listed in Table S1. The value of $\mathrm{K}^{\prime}$ increased about 1.2 times as $\mathrm{pH}$ from 3 to 6 and 1.8 times as $\mathrm{pH}$ from 7 to 11; however, the lowest rate was found at $\mathrm{pH} 7$. Besides, it was observed that the TN removal efficiencies were close at $\mathrm{pH}$ values of 6,9 , and 11 . This phenomenon might be associated with the effects of $\mathrm{pH}$ value on $\mathrm{NO}_{3}{ }^{-}, \mathrm{NO}_{2}{ }^{-}$, and $\mathrm{NH}_{4}{ }^{+}$removals. As shown in Figure S3, acidic condition was more favorable for $\mathrm{NO}_{3}{ }^{-}$and $\mathrm{NO}_{2}{ }^{-}$reduction than neutral or alkaline condition due to the $\mathrm{H}$-atom adsorbed on the surface of electrode, which was necessary for the $\mathrm{NO}_{3}{ }^{-} / \mathrm{NO}_{2}{ }^{-}$indirect reduction [47]. However, a small quantity of $\mathrm{NO}$ was detected as by-product (Equation (3)) under the strong acid condition $(\mathrm{pH} \leq 3)$ [48]. Moreover, Figure S3 displays that the removal efficiency of $\mathrm{NH}_{4}{ }^{+}$was negative, suggesting that more $\mathrm{NH}_{4}{ }^{+}$was generated in electrolysis rather than being removed. This could be explained by 
the over-reduction of $\mathrm{NO}_{3}{ }^{-} / \mathrm{NO}_{2}{ }^{-}$; i.e., $\mathrm{NH}_{4}{ }^{+}$was generated as by-product in the process, indicating that the side reaction of over-reduction was the fundamental reason for limiting the TN removal in this electrochemical system. Taking into account the above results, initial $\mathrm{pH}$ value of 6 was selected for the further experiments.

$$
3 \mathrm{NO}_{2}^{-}+\mathrm{NO}_{3}^{-}+6 \mathrm{e}^{-}+10 \mathrm{H}^{+} \rightarrow 5 \mathrm{H}_{2} \mathrm{O}+4 \mathrm{NO}_{(\mathrm{g})}
$$
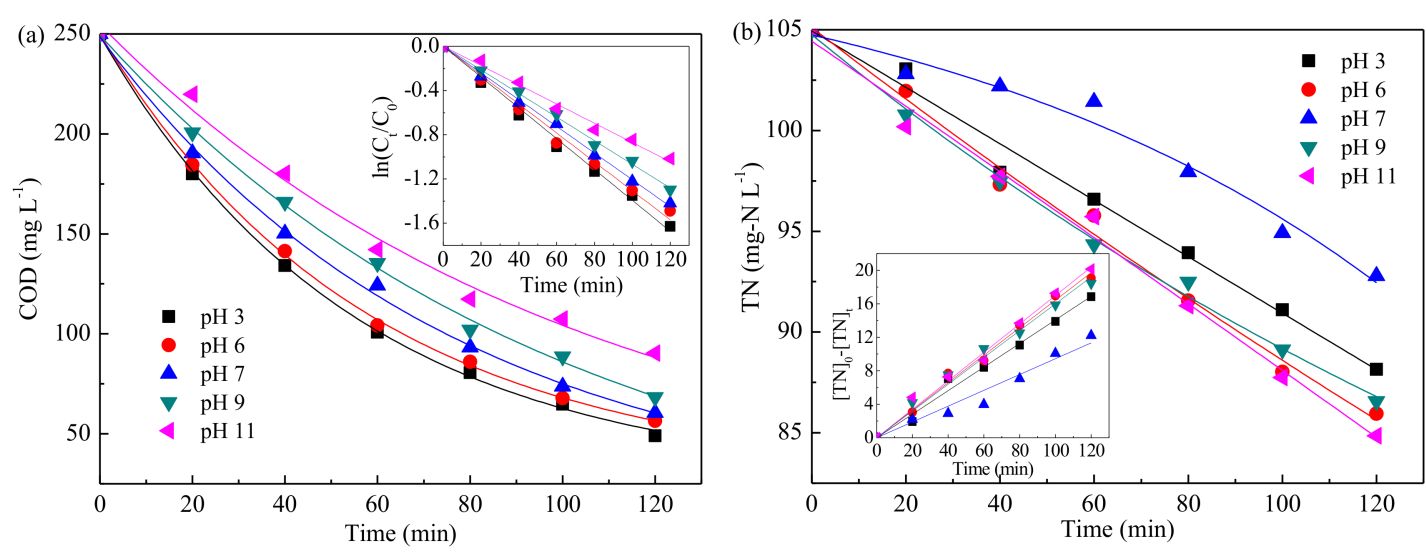

Figure 3. Effect of initial $\mathrm{pH}$ on $\mathrm{COD}(\mathbf{a})$ and $\mathrm{TN}(\mathbf{b})$ removal $\left(\mathrm{no} \mathrm{Cl}^{-}, 10.0 \mathrm{~mA} \cdot \mathrm{cm}^{-2}\right.$, diluted H2SO4, and $\mathrm{NaOH}$ solutions were used for $\mathrm{pH}$ adjustments, and $\mathrm{pH} 6$ was the natural $\mathrm{pH}$ of simulated wastewater).

\subsubsection{Effect of Chloride Concentration}

Figure 4 shows the simultaneous removal of $\mathrm{COD}$ and $\mathrm{TN}$ with the $\mathrm{Cl}^{-}$concentration varied from 0 to $1500 \mathrm{mg} \cdot \mathrm{L}^{-1}$. The results indicated that, as $\mathrm{Cl}^{-}$was added, the removal of COD improved from $77.4 \%\left(0 \mathrm{mg} \cdot \mathrm{L}^{-1} \cdot \mathrm{Cl}^{-}\right)$to $88.6 \%\left(250 \mathrm{mg} \cdot \mathrm{L}^{-1} \cdot \mathrm{Cl}^{-}\right)$, then increased slightly when further increasing $\mathrm{Cl}^{-}$concentration. The TN removal efficiency increased from $18.1 \%$ to $26.0 \%, 46.7 \%, 82.0 \%$, and $87.0 \%$ with the increase of $\mathrm{Cl}^{-}$from $0 \mathrm{mg} \cdot \mathrm{L}^{-1}$ to $250,500,1000$, and $1500 \mathrm{mg} \cdot \mathrm{L}^{-1}$, respectively. Besides, COD removal at different $\mathrm{Cl}^{-}$ concentrations followed pseudo-first-order kinetics. Meanwhile, the process of TN removal matched a zero-order model as $\mathrm{NH}_{4}{ }^{+}$existed and then fitted on pseudo-first-order kinetics as $\mathrm{NH}_{4}{ }^{+}$removed completely. According to the removal efficiency and rate constant, it seemed that $\mathrm{Cl}^{-}$concentration of $1000 \mathrm{mg} \cdot \mathrm{L}^{-1}$ was suitable for the next investigations.
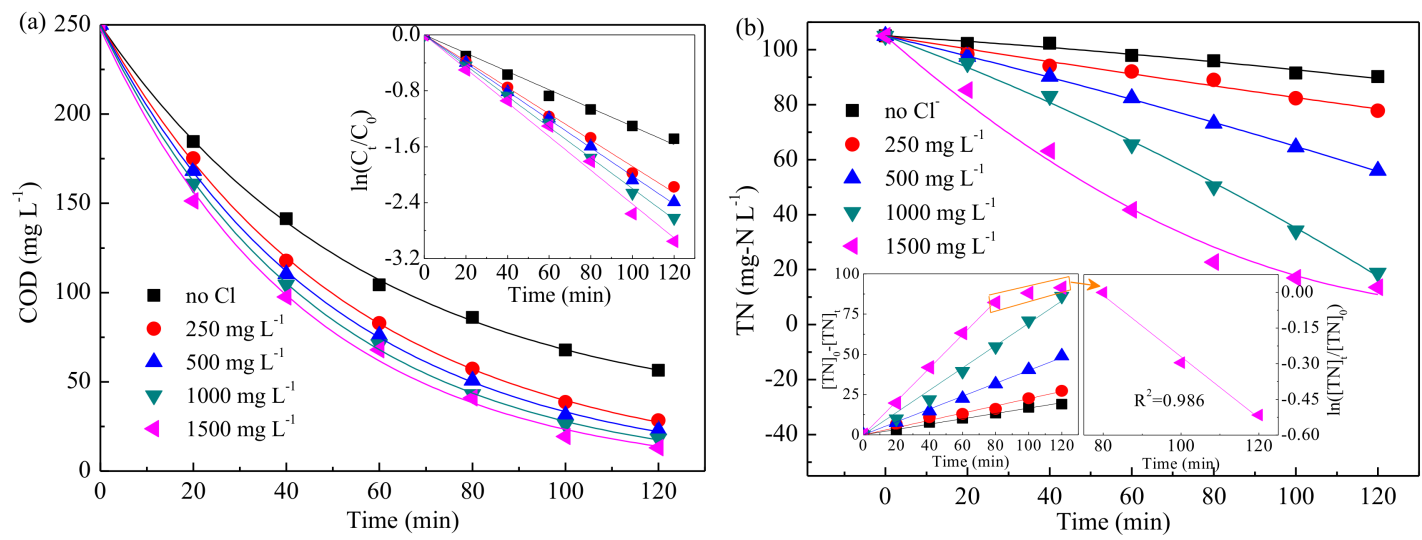

Figure 4. Influence of $\mathrm{Cl}^{-}$concentration on $\operatorname{COD}(\mathbf{a})$ and $\mathrm{TN}(\mathbf{b})$ removal. $\left(\mathrm{pH}=6,10.0 \mathrm{~mA} \cdot \mathrm{cm}^{-2}\right)$.

\subsubsection{Effect of Current Density}

Figure 5 shows that increase of current density was beneficial to enhance the COD and TN removal efficiencies. The COD removal efficiency increased from $78.4 \%$ to $95.3 \%$ as current density increased from 5.0 to $12.5 \mathrm{~mA} \mathrm{~cm}^{-2}$; meanwhile, the TN removal 
efficiency increased from $72.6 \%$ to $86.0 \%$. Figure 5 also displays that the pseudo-firstorder and zero-order kinetics were still suitable for describing the COD and TN removal, respectively. As shown in Table S1, when current density improved from 5.0 to $12.5 \mathrm{~mA} \cdot \mathrm{cm}^{-2}$, the corresponding rate constant for COD removal increased from $1.269 \times 10^{-2}$ to $2.471 \times 10^{-2} \mathrm{~min}^{-1}$; and rate constant for TN raised from 6.032 to $7.918 \mathrm{mg} \cdot \mathrm{L}^{-1} \cdot \mathrm{min}^{-1}$. Though increasing current density was conducive to pollutant removal, the energy consumption would increase obviously. Current density of $10 \mathrm{~mA} \cdot \mathrm{cm}^{-2}$ was thus selected as the optimal one.
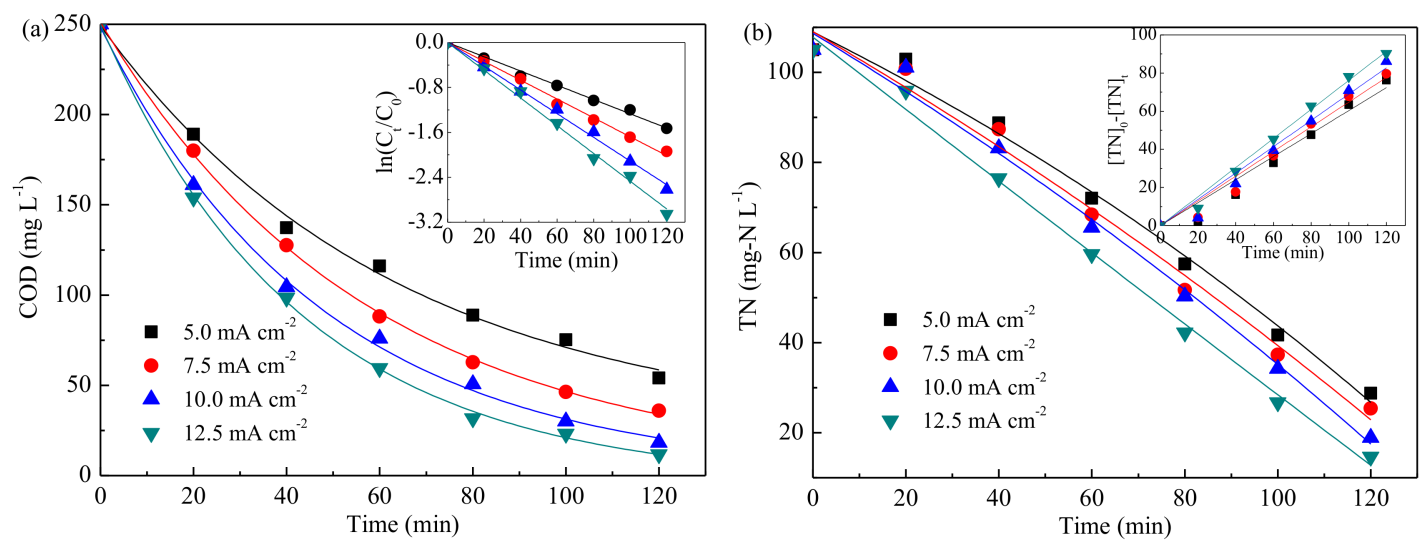

Figure 5. Effect of current density on $\mathrm{COD}(\mathbf{a})$ and $\mathrm{TN}(\mathbf{b})$ removal. $\left(\mathrm{pH}=6,1000 \mathrm{mg} \mathrm{L}^{-1} \mathrm{Cl}^{-}\right)$.

\subsection{Verification of Actual Wastewater Treatment}

Considering to literatures and experimental results, a mechanistic model of electrochemical treatment of COD and TN containing wastewater in a divided electrolysis cell is proposed in Figure 6 [4,24]. In the process, the by-product of $\mathrm{NH}_{4}{ }^{+}$generated during $\mathrm{NO}_{3}{ }^{-} / \mathrm{NO}_{2}{ }^{-}$reduction was circulated into anode chamber by loop operation and then oxidized to $\mathrm{N}_{2}$ on anode; meanwhile, the $\mathrm{NO}_{3}{ }^{-} / \mathrm{NO}_{2}{ }^{-}$as the over-oxidation by-product of $\mathrm{NH}_{4}{ }^{+}$could be recirculated into the cathode chamber and continuously reduced to $\mathrm{N}_{2}$. This process could relieve the common issues of over-reduction and over-oxidation by combining cathodic $\mathrm{NO}_{3}{ }^{-} / \mathrm{NO}_{2}{ }^{-}$reduction with anodic $\mathrm{COD} / \mathrm{NH}_{4}{ }^{+}$oxidation and thus improve the TN removal.

To further investigate the feasibility for COD and TN removal by this electrochemical method, an actual pharmaceutical wastewater was sampled and treated in this study. Figure 7 shows the variations of COD and TN removal with electrolysis time. As shown, COD was effectively reduced from 337.57 to $70.64 \mathrm{mg} \cdot \mathrm{L}^{-1}$ with the removal efficiency of $79.1 \%$. Moreover, similar to the simulated wastewater treatment, COD removal in actual wastewater treatment followed pseudo-first-order kinetics. Figure $7 \mathrm{~b}$ shows that the TN removal efficiency reached $87.0 \%$; and no $\mathrm{NH}_{4}{ }^{+}$or $\mathrm{NO}_{2}{ }^{-}$was detected after $120 \mathrm{~min}$ treatment, while $\mathrm{NO}_{3}{ }^{-}$was removed from 28.33 to $15.69 \mathrm{mg} \cdot \mathrm{L}^{-1}$. The concentrations of nitrogen oxides were under the detection limit. In addition, Figure $7 \mathrm{~b}$ shows that, with the presence of $\mathrm{NH}_{4}{ }^{+}$, TN removal followed zero-order kinetics model; however, when $\mathrm{NH}_{4}{ }^{+}$ was completely removed, pseudo-first-order kinetics was fitted. After 120 min electrolysis, the dissolved concentration of $\mathrm{Pb}^{2+}$ was measured to evaluate the safety of the treated wastewater; it was found that $\mathrm{Pb}^{2+}$ concentration was $0.008 \mathrm{mg} / \mathrm{L}$, which met the Standard for Drinking Water Quality in China (plumbum $\leq 0.01 \mathrm{mg} / \mathrm{L}$ ). Beside, with removal of $79.1 \% \mathrm{COD}$ and $87.0 \% \mathrm{TN}$, the energy consumption was calculated as $13.3 \mathrm{kWh} \cdot \mathrm{m}^{-3}$, which was much lower than that of traditional electrochemical method reported by other authors (Table S2). Meanwhile, compared with biological method, the electrochemical process in this work exhibited remarkable superiorities, such as high efficiency, short treatment time, and easy operation $[49,50]$. 


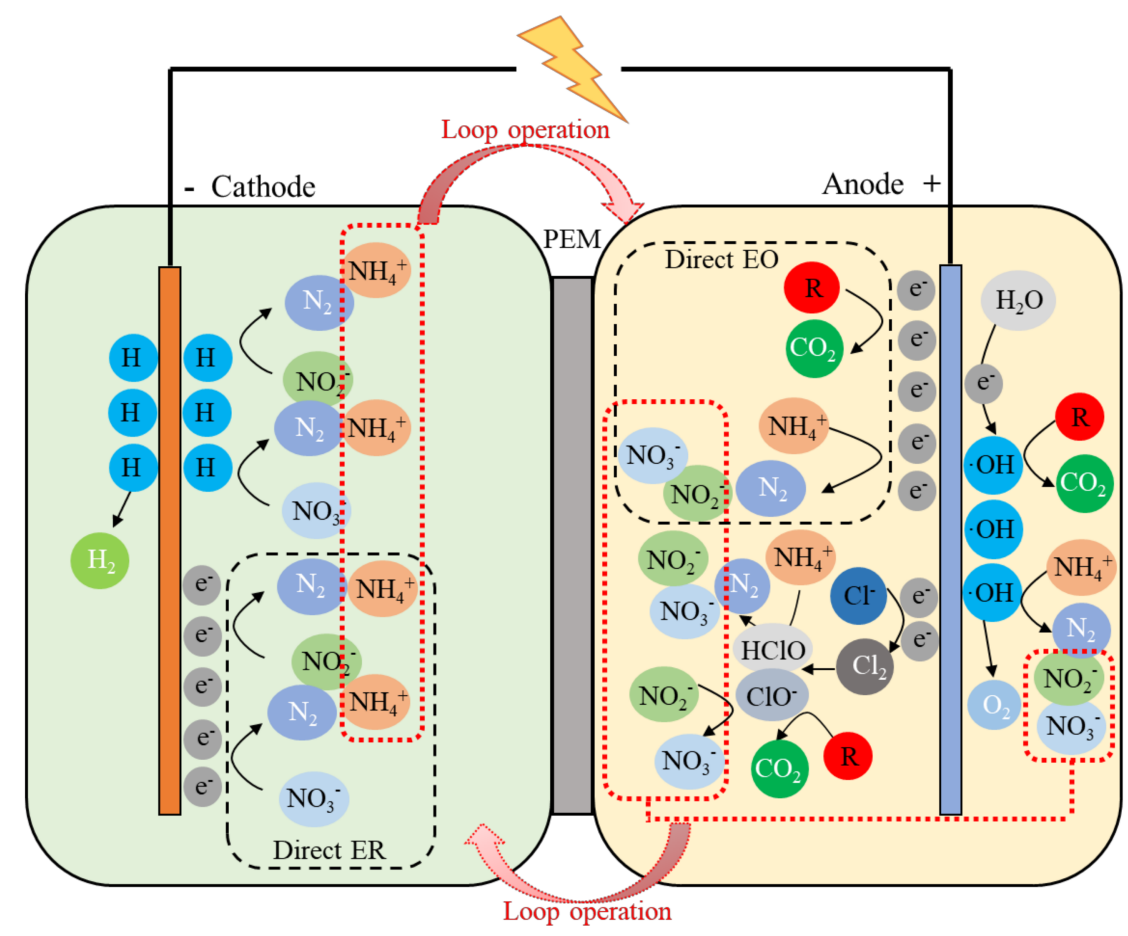

Figure 6. Schematic diagram of the electrolysis system. ER, electrochemical reduction; EO, electrochemical oxidation; $\mathrm{R}$, organic compounds; PEM, proton-exchange membrane.
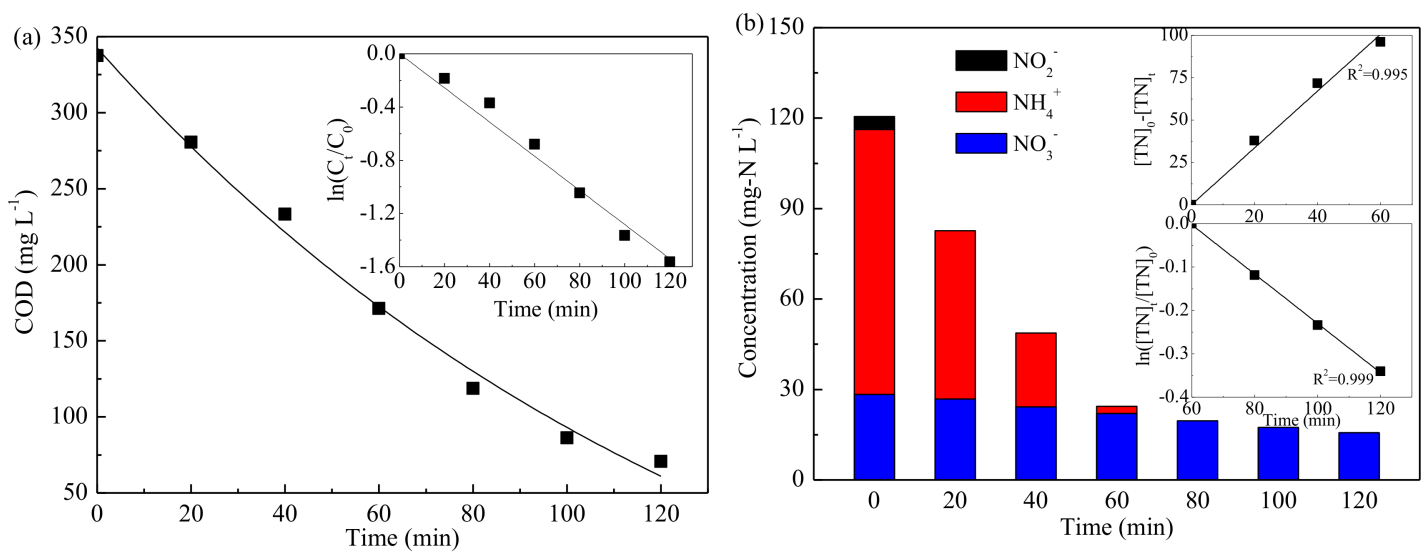

Figure 7. The simultaneous removal of COD (a) and total nitrogen (b) in actual pharmaceutical wastewater treatment.

\section{Conclusions}

This work optimized the electrochemical treatment of COD and TN containing wastewater with a divided cell. The effects of cathode material, initial $\mathrm{pH}$ value, $\mathrm{Cl}^{-}$concentration, and current density were investigated on the COD and TN removal. At an optimized $\mathrm{pH}$, $\mathrm{Cl}^{-}$concentration of $1000 \mathrm{mg} \cdot \mathrm{L}^{-1}$, and current density of $10 \mathrm{~mA} \cdot \mathrm{cm}^{-2}$, this method could remove $92.7 \% \mathrm{COD}$ and $82.0 \% \mathrm{TN}$ in simulated wastewater using $\mathrm{Ti}$ cathode and $\mathrm{Ti} / \mathrm{PbO}_{2}$ anode. Besides, kinetics and reaction mechanism were also proposed to describe the electrochemical process of COD and TN removal. For treatment of an actual pharmaceutical wastewater, the extents of COD and $\mathrm{TN}$ removal were $79.1 \%$ and $87.0 \%$, respectively. 
Supplementary Materials: The following are available online at https: / www.mdpi.com/article/ 10.3390/ijerph19020850/s1: Table S1, The efficiencies for COD and TN removal at different initial $\mathrm{pH}$ values, $\mathrm{Cl}^{-}$concentrations, and current densities; Table S2, Selected results reported on energy consumption of actual wastewater treatment by electrochemical method; Figure S1, Schematic diagram of the divided electrolysis cell; Figure S2, Schematic diagram of in-situ FTIR; Figure S3, Influence of initial $\mathrm{pH}$ on $\mathrm{NO}_{3}{ }^{-}, \mathrm{NO}_{2}{ }^{-}$, and $\mathrm{NH}_{4}{ }^{+}$variations.

Author Contributions: Investigation, writing-review and editing, J.Y.; formal analysis, Y.M.; data curation, J.J. and G.X.; writing-review and editing, J.C. All authors have read and agreed to the published version of the manuscript.

Funding: This research was funded by the National Natural Science Foundation of China (NO.51878614), and the Talent Introduction Project of Zhejiang Shuren University (2019R023).

Institutional Review Board Statement: Not applicable.

Informed Consent Statement: Not applicable.

Data Availability Statement: All data are fully available without restriction. All relevant data are within the manuscript and its Supporting Information files.

Acknowledgments: The authors are very grateful for the insightful comments and suggestions of the anonymous reviewers and the editor, which have helped to significantly improve this article.

Conflicts of Interest: The authors declare no conflict of interest.

\section{References}

1. Tanikawa, D.; Kataoka, T.; Ueno, T.; Minami, T.; Motokawa, D.; Itoiri, Y.; Kimura, Z. Seeding the drainage canal of a wastewater treatment system for the natural rubber industry with rubber for the enhanced removal of organic matter and nitrogen. Chemosphere 2021, 283, 131233. [CrossRef]

2. Munavalli, G.R.; Sonavane, P.G.; Koli, M.M.; Dhamangaokar, B.S. Field-scale decentralized domestic wastewater treatment system: Effect of dynamic loading conditions on the removal of organic carbon and nitrogen. J. Environ. Manag. 2022, $302,114014$. [CrossRef]

3. Pourbavarsad, M.S.; Jalalieh, B.J.; Harkins, C.; Sevanthi, R.; Jackson, W.A. Nitrogen oxidation and carbon removal from high strength nitrogen habitation wastewater with nitrification in membrane aerated biological reactors. J. Environ. Chem. Eng. 2021, 9 , 106271. [CrossRef]

4. Ding, J.; Zhao, Q.L.; Zhang, Y.S.; Wei, L.L.; Li, W.; Wang, K. The eAND process: Enabling simultaneous nitrogen-removal and disinfection for WWTP effluent. Water Res. 2015, 74, 122-131. [CrossRef]

5. Nguyen, H.D.; Babel, S. Insights on microbial fuel cells for sustainable biological nitrogen removal from wastewater: A review. Environ. Res. 2022, 204, 112095. [CrossRef]

6. Falås, P.; Wick, A.; Castronovo, S.; Habermacher, J.; Ternes, T.A.; Joss, A. Tracing the limits of organic micropollutant removal in biological wastewater treatment. Water Res. 2016, 95, 240-249. [CrossRef] [PubMed]

7. Noriega-Hevia, G.; Serralta, J.; Secob, A.; Ferrer, J. Economic analysis of the scale-up and implantation of a hollow fibre membrane contactor plant for nitrogen recovery in a full-scale wastewater treatment plant. Sep. Purif. Technol. 2021, 275, 119128. [CrossRef]

8. Kimura, K.; Yamakawa, M.; Hafuka, A. Direct membrane filtration (DMF) for recovery of organic matter in municipal wastewater using small amounts of chemicals and energy. Chemosphere 2021, 277, 130244. [CrossRef]

9. Tong, S.; Zhang, S.X.; Zhao, Y.; Feng, C.P.; Hu, W.W.; Chen, N. Hybrid zeolite-based ion-exchange and sulfur oxidizing denitrification for advanced slaughterhouse wastewater treatment. J. Environ. Sci. 2022, 113, 219-230. [CrossRef]

10. Vincenta, T.T.; Boyer, T.H. Beneficial reuse of treated municipal wastewater and flue gas carbon dioxide via combined ion exchange. J. Water Process Eng. 2020, 37, 101405.

11. Xiao, W.; Jiang, X.P.; Liu, X.; Zhou, W.M.; Garba, Z.N.; Lawan, I.; Wang, L.W.; Yuan, Z.H. Adsorption of organic dyes from wastewater by metal-doped porous carbon materials. J. Clean. Prod. 2021, 284, 124773. [CrossRef]

12. Li, M.; Feng, C.P.; Zhang, Z.Y.; Yang, Y.N.; Chen, R.Z.; Sugiura, N. Simultaneous reduction of nitrate and oxidation of by-products using electrochemical method. J. Hazard. Mater. 2009, 171, 724-730. [CrossRef] [PubMed]

13. Su, L.H.; Li, K.; Zhang, H.B.; Fan, M.H.; Ying, D.W.; Sun, T.H.; Wang, Y.L.; Jia, J.P. Electrochemical nitrate reduction by using a noval $\mathrm{Co}_{3} \mathrm{O}_{4} /$ Ti cathode. Water Res. 2017, 120,1-11. [CrossRef]

14. Garcia-Segura, S.; Ocon, J.D.; Chong, M.N. Electrochemical oxidation remediation of real wastewater effluents-A review. Process Saf. Environ. 2018, 113, 48-67. [CrossRef]

15. Yu, H.; Li, Y.; Zhao, M.; Dong, H.; Yu, H.B.; Zhan, S.H.; Zhang, L. Energy-saving removal of methyl orange in high salinity wastewater by electrochemical oxidation via a novae $\mathrm{Ti} / \mathrm{SnO}_{2}-\mathrm{Sb}$ anode-Air diffusion cathode system. Catal. Today 2015, 258, 156-161. [CrossRef] 
16. Qiao, J.; Xiong, Y.Z. Electrochemical oxidation technology: A review of its application in high-efficiency treatment of wastewater containing persistent organic pollutants. J. Water Process Eng. 2021, 44, 102308. [CrossRef]

17. Ganzoury, M.A.; Ghasemian, S.; Zhang, N.; Yagar, M.; de Lannoy, C.F. Mixed metal oxide anodes used for the electrochemical degradation of a real mixed industrial wastewater. Chemosphere 2022, 286, 131600. [CrossRef] [PubMed]

18. Markou, V.; Kontogianni, M.C.; Frontistis, Z.; Tekerlekopoulou, A.G.; Katsaounis, A.; Vayenas, D. Electrochemical treatment of biologically pre-treated dairy wastewater using dimensionally stable anodes. J. Environ. Manag. 2017, 202, 217-224. [CrossRef] [PubMed]

19. Zhou, Y.; Zhao, K.; Hu, C.Z.; Liu, H.J.; Wang, Y.; Qu, J.H. Electrochemical oxidation of ammonia accompanied with electricity generation based on reverse electrodialysis. Electrochim. Acta 2018, 269, 128-135. [CrossRef]

20. Zöllig, H.; Fritzsche, C.; Morgenroth, E.; Udert, K.M. Direct electrochemical oxidation of ammonia on graphite as a treatment option for stored source-separated urine. Water Res. 2015, 69, 284-294. [CrossRef]

21. Ghazouani, M.; Akrout, H.; Bousselmi, L. Nitrate and carbon matter removals from real effluents using Si/BDD electrode. Environ. Sci. Pollut. Res. 2017, 24, 9895-9906. [CrossRef]

22. Couto, A.B.; Oishi, S.S.; Ferreira, N.G. Enhancement of nitrate electroreduction using BDD anode and metal modified carbon fiber cathode. J. Ind. Eng. Chem. 2016, 39, 210-217. [CrossRef]

23. Yao, J.C.; Pan, B.J.; Shen, R.X.; Yuan, T.B.; Wang, J.D. Differential control of anode/cathode potentials of paired electrolysis for simultaneous removal of chemical oxygen demand and total nitrogen. Sci. Total Environ. 2019, 687, 198-205. [CrossRef] [PubMed]

24. Mook, W.T.; Chakrabarti, M.H.; Aroua, M.K.; Khan, G.M.A.; Ali, B.S.; Islam, M.S.; Abu Hassan, M.A. Removal of total ammonia nitrogen (TAN), nitrate and total organic carbon (TOC) from aquaculture wastewater using electrochemical technology: A review. Desalination 2012, 285, 1-13. [CrossRef]

25. Yao, J.C.; Mei, Y.; Yuan, T.B.; Chen, J.; Pan, H.; Wang, J.D. Electrochemical removal of nitrate from wastewater with a Ti cathode and $\mathrm{Pt}$ anode for high efficiency and $\mathrm{N}_{2}$ selectivity. J. Electroanal. Chem. 2021, 882, 115019. [CrossRef]

26. Cirmi, D.; Aydin, R.; Koleli, F. The electrochemical reduction of nitrate ion on polypyrrole coated copper electrode. J. Electroanal. Chem. 2015, 736, 101-106. [CrossRef]

27. Shih, Y.J.; Huang, Y.H.; Huang, C.P. Electrocatalytic ammonia oxidation over a nickel foam electrode: $\mathrm{Role}$ of $\mathrm{Ni}(\mathrm{OH})_{2(\mathrm{~s})} \mathrm{-NiOOH}(\mathrm{s})^{-\mathrm{N}}$ nanocatalysts. Electrochim. Acta 2018, 263, 261-271. [CrossRef]

28. Li, M.; Feng, C.P.; Zhang, Z.Y.; Yang, S.J.; Sugiura, N. Treatment of nitrate contaminated water using an electrochemical method. Bioresour. Technol. 2010, 101, 6553-6557. [CrossRef]

29. Li, W.; Xiao, C.W.; Zhao, Y.; Zhao, Q.Q.; Fan, R.; Xue, J.J. Electrochemical reduction of high-concentrated nitrate using Ti/TiO 2 nanotube array anode and Fe cathode in dual-chamber cell. Catal. Lett. 2016, 146, 2585-2595. [CrossRef]

30. Mandal, P.; Dubry, B.K.; Gupta, A.K. Review on landfill leachate treatment by electrochemical oxidation: Drawbacks, challenges and future scope. Waste Manag. 2017, 69, 250-273. [CrossRef]

31. Zou, J.X.; Peng, X.L.; Li, M.; Xiong, Y.; Wang, B.; Dong, F.Q.; Wang, B. Electrochemical oxidation of COD from real textile wastewaters: Kinetic study and energy consumption. Chemosphere 2017, 171, 332-338. [CrossRef] [PubMed]

32. Chen, J.M.; Xia, Y.J.; Dai, Q.Z. Electrochemical degradation of chloramphenicol with a novel Al doped $\mathrm{PbO}_{2}$ electrode: Performance, kinetics and degradation mechanism. Electrochim. Acta 2015, 165, 277-287. [CrossRef]

33. Yao, J.C.; Chen, A.N.; Ye, R.H.; Wang, J.D.; Pan, H.; Xu, D.M.; Chen, J.; Mei, Y.; Hrynsphan, D.; Savitskaya, T. Stepping control of electrochemical process for simultaneous removal of COD and ammonia with high efficiency and energy saving. J. Electrochem. Soc. 2021, 168, 023502. [CrossRef]

34. Chen, G.H. Electrochemcial technologies in wastewater treatment. Sep. Purif. Technol. 2004, 38, 11-41. [CrossRef]

35. Yao, J.C.; Zhou, M.M.; Wen, D.N.; Xue, Q.W.; Wang, J.D. Electrochemical conversion of ammonia to nitrogen in non-chlorinated aqueous solution by controlling pH value. J. Electroanal. Chem. 2016, 776, 53-58. [CrossRef]

36. Zhu, R.Y.; Yang, C.Y.; Zhou, M.M.; Wang, J.D. Industrial park wastewater deeply treated and reused by a novel electrochemical oxidation reactor. Chem. Eng. J. 2015, 260, 427-433. [CrossRef]

37. Li, M.; Feng, C.P.; Zhang, Z.Y.; Sugiura, N. Efficient electrochemical reduction of nitrate to nitrogen using $\mathrm{Ti}^{2} \mathrm{IrO} \mathrm{I}_{2}-\mathrm{Pt}$ anode and different cathodes. Electrochim. Acta 2009, 54, 4600-4606. [CrossRef]

38. Dia, O.; Drogui, P.; Buelna, G.; Dubé, R. Strategical approach to prevent ammonia formation during electrocoagulation of landfill leachate obtained from a biofiltration process. Sep. Purif. Technol. 2017, 189, 253-259. [CrossRef]

39. Reyter, D.; Bélanger, D.; Roué, L. Optimization of the cathode material for nitrate removal by a paired electrolysis process. $J$. Hazard. Mater. 2011, 192, 507-513. [CrossRef] [PubMed]

40. Griffiths, P.R.; de Haseth, J.A. Fourier Transform Infrared Spectrometry; Johnwiley \& Sons: Hoboken, NJ, USA, 1986.

41. Kapałka, A.; Cally, A.; Neodo, S.; Comninellis, C.; Wächter, M.; Udert, K.M. Electrochemical behavior of ammonia at Ni/Ni(OH) 2 electrode. Electrochem. Commun. 2010, 12, 18-21. [CrossRef]

42. Anglada, A.; Urtiaga, A.; Ortiz, I. Pilot scale performance of the electro-oxidation of landfill leachate at boron-doped diamond anodes. Environ. Sci. Technol. 2009, 43, 2035-2040. [CrossRef] [PubMed]

43. Yang, J.B.; Du, C.W.; Shen, Y.Z.; Jian, J.M. Rapid determination of nitrate in Chinese cabbage using fourier transforms mid-infrared spectroscopy. Chin. J. Anal. Chem. 2013, 41, 1264-1268. [CrossRef]

44. Valverde, J.L.; de Lucas, A.; Dorado, F.; Romero, A.; Garcia, P.B. Study by in situ FTIR of the SCR of NO by propene on Cu ${ }^{2+}$ ion-exchanged Ti-PILC. J. Mol. Catal. A-Chem. 2005, 230, 23-28. [CrossRef] 
45. Talhi, B.; Monette, F.; Azzouz, A. Effective and selective nitrate electroreduction into nitrogen through synergistic parameter interactions. Electrochim. Acta 2011, 28, 276-284. [CrossRef]

46. Zhao, J.; Zhu, C.Z.; Lu, J.; Hu, C.J.; Peng, S.C.; Chen, T.H. Electro-catalytic degradation of bisphenol $\mathrm{A}_{\text {with }}$ modified Co $\mathrm{O}_{4} / \beta_{-}$ $\mathrm{PbO}_{2}$ /Ti electrode. Electrochim. Acta 2014, 118, 169-175. [CrossRef]

47. Wang, Y.; Qu, J.H.; Wu, R.C.; Lei, P.J. The electrocatalytic reduction of nitrate in water on Pd/Sn-modified activated carbon fiber electrode. Water Res. 2006, 40, 1224-1232. [CrossRef]

48. Lacasa, E.; Cañizares, P.; Llanos, J.; Rodrigo, M.A. Effect of the cathode material on the removal of nitrates by electrolysis in non-chloride media. J. Hazard. Mater. 2012, 213-214, 478-484. [CrossRef] [PubMed]

49. Cai, Q.Q.; Wu, M.Y.; Li, R.; Deng, S.H.; Lee, B.C.Y.; Ong, S.L.; Hu, J.Y. Potential of combined advanced oxidation-Biological process for cost-effective organic matters removal in reverse osmosis concentrate produced from industrial wastewater reclamation: Screening of AOP pre-treatment technologies. Chem. Eng. J. 2020, 389, 123419. [CrossRef]

50. Bustillo-Lecompte, C.F.; Mehrvar, M. Treatment of an actual slaughterhouse wastewater by integration of biological and advanced oxidation processes: Modeling, optimization, and cost-effectiveness analysis. J. Environ. Manag. 2016, 182, 651-666. [CrossRef] 